\title{
TECHNICAL CHARACTERIZATION OF ECO-COMPATIBLE PLASTIC FILMS FOR SOIL SOLARIZATION: FOUR YEARS OF EXPERIMENTS
}

\author{
Salvatore Margiotta
}

\section{Introduction}

In recent years the necessity to interconnect rural and agricultural sectors with territorial, environmental and landscape safeguarding policies has become a question of great urgency. In the view of a more modernized and ecologically compatible agricultural practice, it is necessary that farmers pay close attention to the environmental questions related to their agricultural practices. In fact, by applying certain agronomical and production methods, they can be the cause of ecological imbalances which are often irreversible.

In this view, about the various techniques used to control soil borne pathogens and weeds, soil solarization has become a more and more important alternative to the use of chemicals, particularly because of the methyl bromide phase-out in $2005[1,6]$.

Solarization is a hydrothermal process to control soil borne pathogens that consists in cover the soil with sheets of transparent plastic films during the warmest period of the year [7]. The use of plastic films in this technique, that is basically environmentally-friendly, can cause a serious drawback regarding the disposal of used plastic sheets [11].

It has been found that all over the world plastic materials in agriculture are used in quantities so high that it is necessary to confront and resolve the consequential environmental problem tied to the disposal after their use [16].

This problem is of great relevance considering that actually 3,400,000 tons/year [13] of plastics are consumed worldwide and, among them, about 650,000 tons/year are used for mulching, 168,000 tons/year for small tunnels and 450,000 tons to cover big tunnels and greenhouses [5].

In Italy, recent data prove that plastic materials used in agriculture are about 345,000 tons/year of which 129,875 tons/year of them are employed for

Paper received 22.04.2006; accepted 07.11.2007

Prof. Ing. SALVATORE MARgiotTA, margiotta@unibas.it, associate professor, Di.T.Ec. Dept., University of Basilicata, Viale dell'Ateneo Lucano, 10 - 85100 Potenza (Italy). mulching, protected vegetable crops and flowers culture [13].

One of the solutions to the problem of waste plastics, of great interest from an environmental point of view, lies in the location and utilization of innovative materials such as ultrathin co-extruded and biodegradable plastic films. Under the same weight as the traditional materials, the ultra thin ones allow to cover a wider area and to produce a lower quantity of plastic waste per surface measure. On the other hand, degradable plastic materials are able to start up spontaneous degradation processes that avoids their collection and their consequent disposal, since they can be degraded directly in the soil [12].

Therefore, it is necessary under these circumstances to verify if these materials, although being lighter and having biodegradability properties, are able to ensure comparatively levels of technical use as high as those found in traditional plastic materials.

The aim of this paper is to summarize the results obtained after four soil solarization trials conducted in Southern Italy, both in greenhouse and in open field, during 1999, 2000, 2002 and 2003 summers, in which mechanical, spectroradiometrical and thermal performances of three innovative plastic films, a multilayered ultrathin co-extruded one and two biodegradable ones, were compared with two traditional films made respectively of EVA and LDPE.

\section{Innovative plastic films used in agriculture: state of the art}

The present scenario of innovation in plastic films for applications in agriculture can be summarized as follows [9]:

- production of innovatory materials having thickness that can be significantly smaller than the traditional ones thanks to a corresponding percentage increase of their mechanical resistance;

- production of manufactured goods that spontaneously degrade at the end of their application, thus avoiding waste collection: the residues of the degraded material can be incorporated in the agri- 
cultural soil without altering its chemical and physical constitution or undergone to composting.

The first solution consents to have a reduction of plastic material per covered unit area; the second one permits to have the absence of recovery costs of the post-consumption material. Both can be considered highly innovatory for the environment.

An innovative and ecologically compatible method to produce films having a better thermal effect as well as mechanical preformances is the co-extrusion. This technique allows to manufacture "multi-layered" plastic sheets that combine values of the LDPE's mechanical resistance and low far IR transmittance of the EVA, without obscuring the favorable fluidity index or the anti-adherence and anti-dust properties of the sheet. Furthermore, the co-extrusion method allows to obtain very thin plastic sheets $(<30 \mu \mathrm{m})$ and to optimize the use of various additives. In fact, each of these can only be selectively mixed with the polymer that will make up a specific layer of the product. Mineral charges can be used in this way for the internal layer made up of EVA, improving its greenhouse effect, while the stabilizers, such as HALS, can be used for the LDPE layer on the outside of the film. On the other hand, the tensioactive, used in order to produce the anti-leak effect, can be added to the sheet found on the inner layer. Finally, the use of plastic co-extruded ultrathin plastic films in agriculture can be considered to have a positive effect, both because it produces lower quantities of plastic material used per unit of surface and, consequently, because it diminishes the amount of post-use of plastic material refuse [4]. Among the negative aspects, one should consider the difficulty of mechanical recycling, since such operation would lead to heterogeneous mixtures of polymers, often with chemical and physical properties inadequate to their use $[3,14]$.

Other innovative environment-friendly plastic films are the biodegradable one. The possibility of using degradable plastic materials in agriculture, and especially in some applications for protected cultivation, like mulching, small tunnels and solarization of agricultural soil, would solve the problem of subsequent disposal of wastes if these materials keep, for the whole duration of their uses, values of mechanical resistance and radiometric properties compatible with the requirements and undergo to a rapid and complete degradation process at the end of the applications. Therefore, there is a researcher growing interest to find degradable plastic films with degradation times compatible with modern agricultural crop cycles. In fact, recently some new polymers, of which degradation comes about in a integral way and in precise determinable time periods, have been developed. Among these new developments, it has been found that thermoplastic material made up of starch have physical properties similar to traditional plastic polymers [17].

The scientific community has taken interest in verifying the mechanical and spectroradiometrical char- acteristics of these innovative plastic films by using laboratory testing aimed at determining some mechanical qualities (ultimate tensile strength, percentage elongation at break and tearing strength resistance) and spectroradiometrical (transmittance, reflectance and absorbance) parameters which allow to express correct judgments about their use in agricultural practices, such as crop mulching and soil solarization.

In this framework, some researchers have taken into consideration solarizing attitudes of four plastic films, two innovative (one biodegradable made up of a corn starch base and one ultra thin co-extruded) and two traditional ones (LDPE and EVA). Of these plastic films levels of mechanical and spectroradiometrical performances and open field solarizing effects were considered. These trials underlined the mulching potential of biodegradable films, especially in greenhouse despite that in open field, and demonstrated their limits, which are due mostly to the rapid abatement of their mechanical performances [10].

Cascone et al. conducted a study which had the aim to compare thermal effects and biological products formed in solarized agricultural terrains by traditional materials, such as EVA, by co-extruded ultra thin plastic materials made specifically for solarization and by biodegradable materials. Mechanical and radiometric properties of the tested plastic films and their variations during the time were evaluated. Results of this study put into evidence that the use of biodegradable films can contribute to limit environment impacts in a very relevant way because it is possible to plough them into the soil after their use, reducing the costs of plastic refuse collection and disposal, that is completely avoiding the dangerous dispersion of these types of material into the environment [2].

\section{Materials and methods}

During the four repeated solarization treatments (table 1), tests have been made using two biodegradable plastic films, the first one made of polyesterammide and the second one made of corn starch, an ultrathin co-extruded film and two traditional plastic films made respectively of EVA and LDPE (table 2).

Mechanical and spectroradiometrical characterization of the films, both fresh and taken every 15 days from the experimental field, have been carried out at the Di.T.Ec. laboratory, by using an universal computerized press Galdabini PMA 10 and two spectrophotometers, one operating in the UV-VIS-NIR and the other in the IR.

Mechanical measurements were conducted for tensile strength, according to the Italian Standard UNI 8422 , and for tearing strength according to the Italian Standard UNI 9563. From the first measurements, the values of ultimate tensile strength and percentage elongation at break were acquired and from the second 


\begin{tabular}{|l|l|}
\hline \multicolumn{1}{|c|}{ Period } & \multicolumn{1}{c|}{ Trial } \\
\hline $\begin{array}{l}\text { summer } 1999 \\
\text { - from the } 17^{\text {th }} \text { July to } \\
\text { the } 23^{\text {rd }} \text { August - }\end{array}$ & $\begin{array}{l}\text { Soil solarization } \\
\text { in greenhouse } \\
\text { and in open field }\end{array}$ \\
\hline $\begin{array}{l}\text { summer } 2000 \\
\text { - from the } 19^{\text {th }} \text { July to to } \\
\text { the } 8^{\text {h }} \text { September - }\end{array}$ & $\begin{array}{l}\text { Soil solarization } \\
\text { in greenhouse } \\
\text { and in open field }\end{array}$ \\
\hline $\begin{array}{l}\text { summer } 2002 \\
\text { - from the } 13^{\text {th }} \text { July to } \\
\text { the } 16^{\text {th }} \text { September }\end{array}$ & $\begin{array}{l}\text { Soil solarization } \\
\text { in greenhouse } \\
\text { and in open field }\end{array}$ \\
\hline $\begin{array}{l}\text { summer } 2003 \\
\text { - from the } 16^{\text {h }} \text { July to } \\
\text { the } 16^{\text {th }} \text { September - }\end{array}$ & $\begin{array}{l}\text { Soil solarization } \\
\text { in greenhouse } \\
\text { and in open field }\end{array}$ \\
\hline
\end{tabular}

TABLE 1 - Period of trials.

measurements, values of tearing strength resistance were found. As required by the Italian Standard UNI 5309 , for each film, at least ten samples, obtained by dinking the plastic sheets according to the previsions of the Italian Standard UNI 5819 for the traction tests and trousers shaped as required by the Italian Standard UNI 9563 for the laceration tests, have been brought to their breakage point, consenting to express the results in terms of average value and trustworthy bilateral intervals with $95 \%$ of probability.

The solarization treatments, according to the timesheet of table 1, were carried out in a farm in Metaponto area in Southern Italy (latitude $40^{\circ} 09^{\prime}$ North - longitude $16^{\circ} 38^{\prime}$ East, $10 \mathrm{~m}$ a.s.l.), using an unheated tunnel greenhouse $(28.8 \mathrm{~m} \times 46.0 \mathrm{~m})$, made from metallic structure, covered by a film of LDPE of $200 \mu \mathrm{m}$ thick, divided into four bays, with a ridge height of $3.80 \mathrm{~m}$ and with a volume/surface index of $3.0 \mathrm{~m}^{3} \mathrm{~m}^{-2}$.

The greenhouse soil was sandy type $(82.7 \%$ sand, $8.9 \%$ limestone and $8.4 \%$ clay), with a $\mathrm{pH}$ of 8.4 , poor in total Nitrogen $\left(0.5 \mathrm{~g} \mathrm{~kg}^{-1}\right)$, very poor in organic matter content $\left(3.3 \mathrm{~g} \mathrm{~kg}^{-1}\right)$ and well-supplied with Phosphorus (28.4 mg kg-1) and with exchangeable Potassium (307.0 $\mathrm{mg} \mathrm{kg}^{-1}$ ).

For each trial, the soil was appropriately milled and irrigate, at the beginning of the treatment, to its field capacity by using a drop irrigation system, that was left under the plastic sheets for all the soil solarization duration, before laying by hand the plastic sheets. Only the central bays were used to verify the solarization suitability for the different plastic films. They were divided into seven plots $(6.5 \mathrm{~m} \times 7.0 \mathrm{~m})$ of witch: two were considered as edges, one was left uncovered as a "control" and the remaining four were covered with the plastic films to be tested (figure 1). Moreover, to record the soil temperatures at depths of $2,10,20$ and $30 \mathrm{~cm}$, at the centre of each plot a column of Pt 100 probes was placed (figure 2).

Inside the greenhouse, air temperature, air moisture and radiation were collected. Similarly, outside the

\begin{tabular}{|c|c|c|c|}
\hline Plastic film & Colour & $\begin{array}{c}\text { Thickness } \\
{[\mu \mathrm{m}]}\end{array}$ & $\begin{array}{c}\text { Year of } \\
\text { use }\end{array}$ \\
\hline $\begin{array}{c}\text { Polyesterammide } \\
\text { biodegradable }\end{array}$ & Transparent & 20 & 1999 \\
\hline $\begin{array}{c}\text { Corn starch } \\
\text { based } \\
\text { biodegradable }\end{array}$ & Lactescent & 20 & 2000 \\
\hline $\begin{array}{c}\text { Corn starch } \\
\text { based } \\
\text { biodegradable }\end{array}$ & Lactescent & 40 & $\begin{array}{c}2002 \\
\text { and } \\
2003\end{array}$ \\
\hline $\begin{array}{l}\text { Co-extruded } \\
\text { three layered }\end{array}$ & Transparent & 30 & 1999 \\
\hline $\begin{array}{l}\text { Co-extruded } \\
\text { three layered }\end{array}$ & Transparent & 20 & $\begin{array}{c}2002 \\
\text { and } \\
2003\end{array}$ \\
\hline EVA & Transparent & 30 & $\begin{array}{c}1999 \\
\text { and } \\
2000\end{array}$ \\
\hline EVA & Transparent & 35 & $\begin{array}{c}2002 \\
\text { and } \\
2003\end{array}$ \\
\hline LDPE & Transparent & 50 & $\begin{array}{c}2002 \\
\text { and } \\
2003\end{array}$ \\
\hline
\end{tabular}

TABLE 2 - Plastic films tested for soil solarization in summers 1999, 2000, 2002 and 2003.

greenhouse meteorological parameters (air temperature, air humidity, wind speed, wind direction, and total radiation) were collected. Acquisition of all data has been performed by two Campbell CR 10X dataloggers.

During each soil solarization treatment, to determine a possible over time plastic degradation, in specific areas of each plot, separated and circumscribed from the remainder, periodical film samplings, with a 


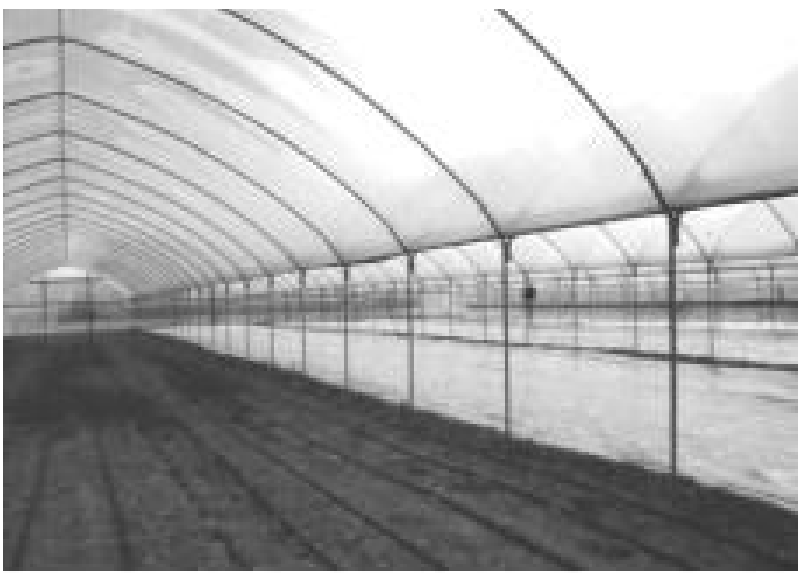

Fig. 1 - Inside of the greenhouse during the solarization.

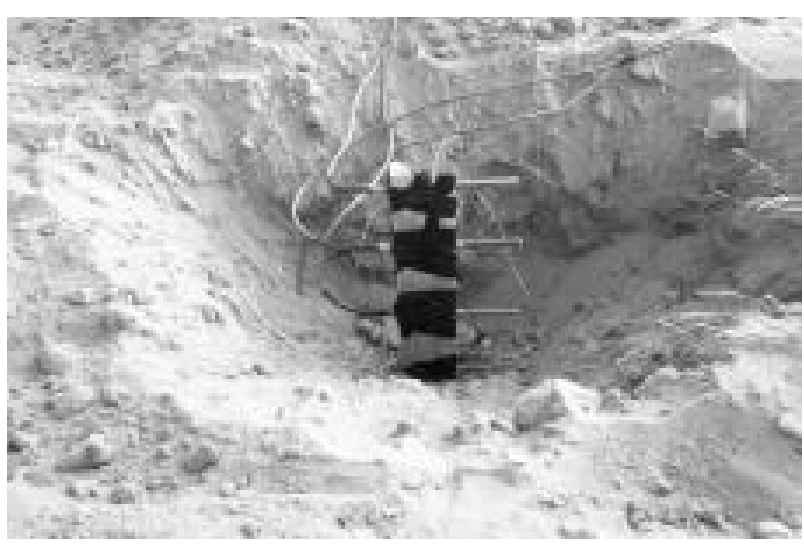

Fig. 2 - Column of Pt 100 probes.

dimension of $20 \times 20 \mathrm{~cm}$, were performed. The little dimension of the samplings and the care of burying the edges of the plastic film in the sampling area at each cut did not influenced significantly both the plot dimension and the general thermal rate of soil solarization.

\section{Results and discussion}

\section{First soil solarization (1999)}

Mechanical trials have showed that the fresh polyesterammide biodegradable film was characterized by a low ultimate tensile strength equal to $12.67 \mathrm{~N}$ $\mathrm{mm}^{-2}$, nevertheless decreasing to half after few days. The fresh co-extruded ultra thin film have had a level of tensile strength of $24.68 \mathrm{~N} \mathrm{~mm}^{-2}$. The fresh EVA film registered ultimate tensile strength values of $29.56 \mathrm{~N} \mathrm{~mm}^{-2}$.

Fresh biodegradable percentage value of elongation at break was $669.23 \%$, the fresh co-extruded ultra thin had the highest value equal to $849.72 \%$ and the EVA sheet had the lowest one of $589.43 \%$.

Spectroradiometrical measurements carried out on the fresh solarizing films have permitted to notice that, in UV-VIS-NIR $[190 \div 2,500] \mathrm{nm}$, the polyester- ammide biodegradable film has had a transmittance similar to the other films; on the contrary, in IR [2,500 $\div 12,500] \mathrm{nm}$ it was the plastic films that has shown the lower transmittance. The co-extruded ultra thin film have had a normal transmittance in UV-VISNIR, while in long IR, after 7,500 $\mathrm{nm}$, it has been presented a high transmittance. The film in EVA have shown high transmittance values in UV-VIS-NIR, but in IR it had lower transmittance values compared to the co-extruded film but a higher respect to the biodegradable film.

From the analysis of the temperature data recorded in the solarized soil during the whole duration of the trial and particularly in the reference period $\left(14^{\text {th }}\right.$ $23^{\text {rd }}$ August 1999) a similar behaviour for EVA and the co-extruded material at different depths were observed. Separate remarks are to be made for the polyesterammide biodegradable film, that, though having spectrophotometer characteristics adequate for its use as solarizing material, did not correspond to expectations because it showed evident signs of degradation since the fifth day from its laying on the soil. Consequently, also its thermal performances were negatively affected by this phenomenon in the subsequent days; whereas, during the first days, when the film was intact, and thus efficient, its thermal behaviour

\begin{tabular}{|c|c|c|c|c|}
\hline $\begin{array}{l}\text { Solarizing } \\
\text { films }\end{array}$ & $\begin{array}{l}\text { Depth } \\
(\mathrm{cm})\end{array}$ & $40-45^{\circ} \mathrm{C}$ & $\begin{array}{c}\text { reenhous } \\
\text { hermal l } \\
46 \text { - } 50 \\
{ }^{\circ} \mathrm{C} \\
\end{array}$ & $\begin{array}{c}51-60 \\
{ }^{\circ} \mathrm{C} \\
\end{array}$ \\
\hline \multirow{4}{*}{$\begin{array}{c}\text { Poly- } \\
\text { esterammide } \\
\text { biodegradable }\end{array}$} & 2 & 96 & 60 & 157 \\
\hline & 10 & 269 & 132 & 14 \\
\hline & 20 & 272 & 0 & 0 \\
\hline & 30 & 43 & 0 & 0 \\
\hline \multirow{4}{*}{ EVA } & 2 & 136 & 83 & 183 \\
\hline & 10 & 263 & 162 & 131 \\
\hline & 20 & 467 & 134 & 0 \\
\hline & 30 & 567 & 4 & 0 \\
\hline \multirow{4}{*}{ Co-extruded } & 2 & 160 & 103 & 204 \\
\hline & 10 & 328 & 200 & 104 \\
\hline & 20 & 523 & 144 & 0 \\
\hline & 30 & 602 & 7 & 0 \\
\hline \multirow{4}{*}{$\begin{array}{c}\text { Control } \\
\text { (uncovered soil) }\end{array}$} & 2 & 96 & 78 & 197 \\
\hline & 10 & 210 & 0 & 0 \\
\hline & 20 & 21 & 0 & 0 \\
\hline & 30 & 0 & 0 & 0 \\
\hline
\end{tabular}

TABLE 3 - Number of hours for temperature range at different soil depth in greenhouse and in open field (1999). 
was similar and in some cases higher to that of all the other films tested.

For better understanding the effectiveness of solarization with respect to the control, the sums of the daily hours during which temperature exceeded the value of $40^{\circ} \mathrm{C}$ were compared (table 3 ), as this is considered the thermal limit beyond which soil borne pathogen inoculums reduced considerably [8]. The calculation of the sum of hours for soil solarization, made in 1999 only for the greenhouse treatment, was prepared by considering that soil sanitation was influenced not only by the temperature level attained, but also by the number of hours during which this level persisted.

\section{Second soil solarization (2000)}

The fresh corn starch based biodegradable film was characterized by a high ultimate tensile strength equal to $28.67 \mathrm{~N} \mathrm{~mm}^{-2}$, that however decreased to less than half after few days. The fresh EVA film has shown an ultimate tensile strength values of $30.27 \mathrm{~N}$ $\mathrm{mm}^{-2}$.

Percentage of elongation at break of the fresh biodegradable was equal to $407.15 \%$, while for the EVA it was of $571.49 \%$.

Thermal trend at different depth have shown that during the reference period $\left(3^{\text {rd }}-9^{\text {th }}\right.$ August 2000) in greenhouse maximal temperatures have been of 56 , 50 e $45^{\circ} \mathrm{C}$ respectively at 10,20 , and $30 \mathrm{~cm}$ of depth, always obtained by the EVA plastic film. A similar situation were observed in open field.

Instead, considering the differences between highest daily temperatures, both in greenhouse and in open field, it is possible to assess that them are higher in greenhouse, from 9 to $12{ }^{\circ} \mathrm{C}$ for EVA and from 8 to $13{ }^{\circ} \mathrm{C}$ for the biodegradable layer. Moreover, results have shown that at $10 \mathrm{~cm}$ depth the biodegradable layer and EVA are effective just in greenhouse and not in open field, as happens also at $20 \mathrm{~cm}$ depth (table 4).

\section{Third and fourth soil solarization (2002 and 2003)}

In both years, the fresh corn starch based biodegradable film presented a good ultimate tensile strength of $26.28 \mathrm{~N} \mathrm{~mm}^{-2}$. However this value was severely reduced t just 15 days after the application, either in samples from the greenhouse and from the open field. The fresh co-extruded film had a high ultimate tensile strength of $50.59 \mathrm{~N} \mathrm{~mm}^{-2}$, that reduced to $45.27 \mathrm{~N} \mathrm{~mm}^{-2}$ and $50.07 \mathrm{~N} \mathrm{~mm}^{-2}$ respectively in greenhouse and in open field after 30 days.

Fresh traditional films gave values of ultimate tensile strength, of $30.10 \mathrm{~N} \mathrm{~mm}^{-2}$ for EVA and of 28.50 $\mathrm{N} \mathrm{mm}^{-2}$ for LDPE (figures 5 and 6).

In 2002 and 2003 trials, percentage elongaion at break of fresh degradable films was of $415.45 \%$, similar to the other tested films, but decreased rapidly, es- pecially in open field, to $25.33 \%$ in 2002 and 15.45 $\%$ in 2003. The fresh co-extruded film had a percentage of elongation at break of $481.25 \%$, that has been kept constant to the end of the soil solarization. A consistent reduction of percentage elongation at break was recorded for EVA film in open field. A peak after 30 days, more evident in open field, followed by a slight decrease, was found for LDPE film (figures 7 and 8).

\begin{tabular}{|c|c|c|c|c|}
\hline \multirow[b]{2}{*}{ Solarizing films } & \multirow[b]{2}{*}{$\begin{array}{c}\text { Depth } \\
(\mathbf{c m})\end{array}$} & \multicolumn{3}{|c|}{$\begin{array}{c}\text { Greenhouse } \\
\text { soil thermal levels }\end{array}$} \\
\hline & & $\begin{array}{c}40 \text { - } 45 \\
{ }^{\circ} \mathrm{C}\end{array}$ & $\begin{array}{c}46-50 \\
{ }^{\circ} \mathrm{C}\end{array}$ & $\begin{array}{c}51-60 \\
{ }^{\circ} \mathrm{C}\end{array}$ \\
\hline \multirow{4}{*}{$\begin{array}{c}\text { Corn starch } \\
\text { based } \\
\text { biodegradable }\end{array}$} & 2 & 107 & 78 & 188 \\
\hline & 10 & 283 & 144 & 21 \\
\hline & 20 & 288 & 5 & 1 \\
\hline & 30 & 55 & 0 & 0 \\
\hline \multirow{4}{*}{ EVA } & 2 & 154 & 99 & 191 \\
\hline & 10 & 265 & 180 & 126 \\
\hline & 20 & 477 & 218 & 9 \\
\hline & 30 & 702 & 0 & 0 \\
\hline \multirow{4}{*}{$\begin{array}{c}\text { Control } \\
\text { (uncovered soil) }\end{array}$} & 2 & 82 & 0 & 0 \\
\hline & 10 & 102 & 0 & 0 \\
\hline & 20 & 0 & 0 & 0 \\
\hline & 30 & 0 & 0 & 0 \\
\hline
\end{tabular}

\begin{tabular}{|c|c|c|c|c|}
\hline \multirow[b]{2}{*}{ Solarizing films } & \multirow[b]{2}{*}{$\begin{array}{l}\text { Depth } \\
(\mathrm{cm})\end{array}$} & \multicolumn{3}{|c|}{$\begin{array}{c}\text { Open field } \\
\text { soil thermal levels }\end{array}$} \\
\hline & & $\begin{array}{c}40 \text { - } 45 \\
{ }^{\circ} \mathrm{C} \\
\end{array}$ & $\begin{array}{c}46-50 \\
{ }^{\circ} \mathrm{C} \\
\end{array}$ & $\begin{array}{c}51-60 \\
{ }^{\circ} \mathrm{C} \\
\end{array}$ \\
\hline \multirow{4}{*}{$\begin{array}{c}\text { Corn starch } \\
\text { based } \\
\text { biodegradable }\end{array}$} & 2 & 96 & 60 & 157 \\
\hline & 10 & 269 & 132 & 14 \\
\hline & 20 & 272 & 0 & 0 \\
\hline & 30 & 43 & 0 & 0 \\
\hline \multirow{4}{*}{ EVA } & 2 & 111 & 41 & 0 \\
\hline & 10 & 261 & 63 & 0 \\
\hline & 20 & 0 & 0 & 0 \\
\hline & 30 & 0 & 0 & 0 \\
\hline \multirow{4}{*}{$\begin{array}{c}\text { Control } \\
\text { (uncovered soil) }\end{array}$} & 2 & 27 & 0 & 0 \\
\hline & 10 & 0 & 0 & 0 \\
\hline & 20 & 0 & 0 & 0 \\
\hline & 30 & 0 & 0 & 0 \\
\hline
\end{tabular}

TABLE 4 - Number of hours for temperature range at different soil depth in greenhouse and in open field (2000). 


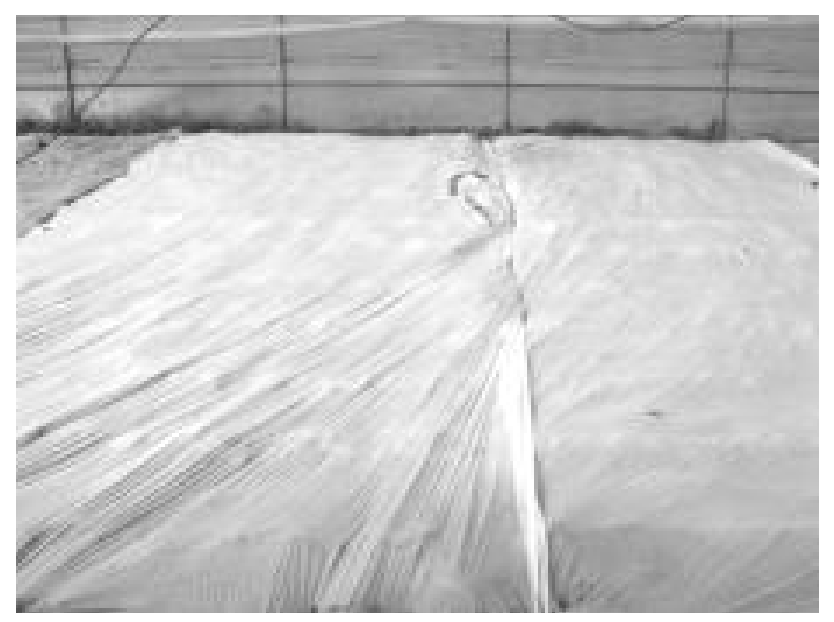

Fig. 3 - Biodegradable plastic film in greenhouse after 16 days from the installation (2003).

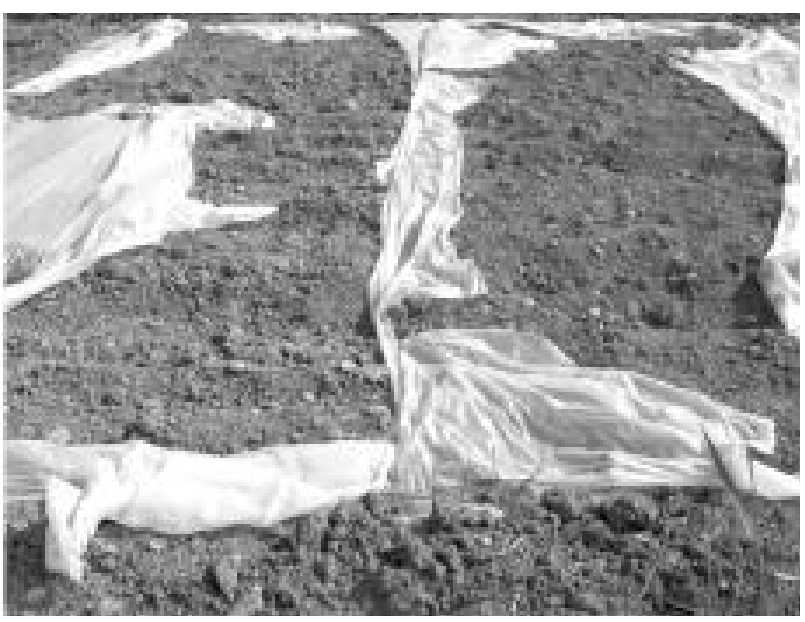

Fig. 4 - Biodegradable film in open field 16 days from the installation (2003).

\begin{tabular}{|c|c|c|c|c|}
\hline \multirow{2}{*}{$\begin{array}{l}\text { Solarizing } \\
\text { films }\end{array}$} & \multirow{2}{*}{$\begin{array}{c}\text { Depth } \\
(\mathbf{c m})\end{array}$} & \multicolumn{3}{|c|}{$\begin{array}{c}\text { Greenhouse } \\
\text { soil thermal levels }\end{array}$} \\
\hline & & $\begin{array}{c}40-45 \\
{ }^{\circ} \mathrm{C} \\
\end{array}$ & $\begin{array}{c}46-50 \\
{ }^{\circ} \mathrm{C} \\
\end{array}$ & $\begin{array}{c}51-60 \\
{ }^{\circ} \mathrm{C} \\
\end{array}$ \\
\hline \multirow{4}{*}{$\begin{array}{c}\text { Corn starch } \\
\text { based } \\
\text { biodegradable }\end{array}$} & 2 & 346 & 299 & 137 \\
\hline & 10 & 562 & 232 & 5 \\
\hline & 20 & 499 & 41 & 0 \\
\hline & 30 & 669 & 0 & 0 \\
\hline \multirow{4}{*}{ Co-Extruded } & 2 & 230 & 163 & 146 \\
\hline & 10 & 425 & 242 & 25 \\
\hline & 20 & 624 & 69 & 0 \\
\hline & 30 & 612 & 0 & 0 \\
\hline \multirow{4}{*}{ EVA } & 2 & 367 & 246 & 112 \\
\hline & 10 & 543 & 242 & 5 \\
\hline & 20 & 702 & 55 & 0 \\
\hline & 30 & 620 & 0 & 0 \\
\hline \multirow{4}{*}{ LDPE } & 2 & 481 & 170 & 152 \\
\hline & 10 & 410 & 261 & 65 \\
\hline & 20 & 705 & 112 & 0 \\
\hline & 30 & 683 & 0 & 0 \\
\hline \multirow{4}{*}{$\begin{array}{l}\text { Control } \\
\text { (uncovered } \\
\text { soil) }\end{array}$} & 2 & 244 & 37 & 0 \\
\hline & 10 & 74 & 0 & 0 \\
\hline & 20 & 0 & 0 & 0 \\
\hline & 30 & 0 & 0 & 0 \\
\hline
\end{tabular}

\begin{tabular}{|c|c|c|c|c|}
\hline \multirow{2}{*}{$\begin{array}{l}\text { Solarizing } \\
\text { films }\end{array}$} & \multirow{2}{*}{$\begin{array}{c}\text { Depth } \\
\text { (cm) }\end{array}$} & \multicolumn{3}{|c|}{$\begin{array}{c}\text { Open field } \\
\text { soil thermal levels }\end{array}$} \\
\hline & & $\begin{array}{c}40 \text { - } 45 \\
{ }^{\circ} \mathrm{C}\end{array}$ & $\begin{array}{c}46-50 \\
{ }^{\circ} \mathrm{C}\end{array}$ & $\begin{array}{c}51-60 \\
{ }^{\circ} \mathrm{C}\end{array}$ \\
\hline \multirow{4}{*}{$\begin{array}{l}\text { Corn starch } \\
\text { based } \\
\text { biodegradable }\end{array}$} & 2 & 116 & 43 & 1 \\
\hline & 10 & 156 & 7 & 0 \\
\hline & 20 & 2 & 0 & 0 \\
\hline & 30 & 0 & 0 & 0 \\
\hline \multirow{4}{*}{ Co-Extruded } & 2 & 154 & 131 & 59 \\
\hline & 10 & 192 & 36 & 0 \\
\hline & 20 & 28 & 0 & 0 \\
\hline & 30 & 0 & 0 & 0 \\
\hline \multirow{4}{*}{ EVA } & 2 & 227 & 119 & 12 \\
\hline & 10 & 137 & 0 & 0 \\
\hline & 20 & 0 & 0 & 0 \\
\hline & 30 & 0 & 0 & 0 \\
\hline \multirow{4}{*}{ LDPE } & 2 & 178 & 142 & 51 \\
\hline & 10 & 189 & 21 & 0 \\
\hline & 20 & 25 & 0 & 0 \\
\hline & 30 & 0 & 0 & 0 \\
\hline \multirow{4}{*}{$\begin{array}{c}\text { Control } \\
\text { (uncovered } \\
\text { soil) }\end{array}$} & 2 & 39 & 2 & 1 \\
\hline & 10 & 0 & 0 & 0 \\
\hline & 20 & 0 & 0 & 0 \\
\hline & 30 & 0 & 0 & 0 \\
\hline
\end{tabular}

TABLE 5 - Number of hours for temperature range at different soil depth in greenhouse and in open field (2002). 
Tearing strength resistance was only measured on the biodegradable film, since all the other films have reported values that were not statistically significant. Tearing strength resistance of biodegradable film, in both 2002 and 2003 treatments, decreased during the first 15 days after application from a value of 178.56 $\mathrm{N} \mathrm{mm}{ }^{-1}$ to a value of $19.73 \mathrm{~N} \mathrm{~mm}^{-1}$, This decrement was more evidently in open field than in greenhouse.

Spectroradiometrical measurements on fresh films showed that the lowest transmittance of biodegradable film was in the UV-VIS-NIR $(190 \div 2,500 \mathrm{~nm})$, probably because of its opaque lactescent colour, whereas in the IR $(2,500 \div 12,500 \mathrm{~nm})$ it was the film that reduced better the soil heat loss, with a very low transmittance in the range $8,000 \div 10,000 \mathrm{~nm}$.

Transmittance of the co-extruded plastic film was found to be high in the UV-VIS-NIR and of $87.34 \%$ in the IR. Transmittance of EVA film was high in the UV-VIS-NIR, whereas in the IR it was lower than LDPE and higher than the biodegradable film. The highest transmittance in the UV-VIS-NIR was found in LDPE film.

In both 2002 and 2003 soil solarization, transmittance of all the plastic films decreased in the UV-VISNIR, more evidently in the range $800 \div 900 \mathrm{~nm}$; a progressive reduction of total transmittance of the films, related to the length of the application period, was found in the long IR.

Regarding the thermal performances of solarizing films it has to point out that in 2002 experiments, at $10 \mathrm{~cm}$ depth in the $40-45{ }^{\circ} \mathrm{C}$ temperature range the corn starch based biodegradable film gave the best performance, followed by EVA, co-extruded an LDE; at $20 \mathrm{~cm}$ depth the film that gave the maximun number of hours was the LDPE followe by EVA, Co-Extruded and corn starch based biodegradable; at $30 \mathrm{~cm}$ depth the co-extruded was the most effective, followed respectively by LDPE, biodegradable and EVA flm (table 5). In open field at $10 \mathrm{~cm}$ depth the co-extruded film gave the best performances followed correspondingly by LDPE, biodegradable and EVA, whereas, at $30 \mathrm{~cm}$ depth, no film exceeded $40{ }^{\circ} \mathrm{C}$ (table 5).

2003 greenhouse experiments showed that, in the range $40-45^{\circ} \mathrm{C}$ at $10 \mathrm{~cm}$ depth, the best films were the LDPE and the biodegradable, whereas in open field only the soil covered with LDPE, EVA and coextruded exceeded $46{ }^{\circ} \mathrm{C}$; at $30 \mathrm{~cm}$ only the co-extruded, the LDPE and the EVA overcame $46{ }^{\circ} \mathrm{C}$ in greenhouse, whereas it was never reached in open field. In the range $51-60{ }^{\circ} \mathrm{C}$, solarized soil exceeded $51{ }^{\circ} \mathrm{C}$ temperature only in greenhouse at $10 \mathrm{~cm}$ and highest number of hours was recorded respectively for EVA, LDPE, co-extruded and biodegradable (table 5). soil temperature performance was reached by the co-extruded, followed by the EVA, the LDPE and the biodegradable; at $30 \mathrm{~cm}$ depth, the EVA, followed by the biodegradable, the LDPE and the co-extruded, totalized the highest numbers of hours (table 6). In open field, EVA resulted the most effective film at $10 \mathrm{~cm}$, and the only film over the $40{ }^{\circ} \mathrm{C}$ at $30 \mathrm{~cm}$ depth. In greenhouse at $10 \mathrm{~cm}$ depth, in the interval $46-50{ }^{\circ} \mathrm{C}$, the best performance was given by the co-extruded, followed by the EVA (table 6).

It has to be noticed that in open field, both in 2002 and 2003 trials, biodegradable sheets have always been teared by the wind after few days behind the installation respect to the greenhouse environment, in which they were always efficient (figures 3 and 4).

This has had a bad influence to the heat capacity of the biodegradable plastic film that made it non perfectly usable in open field.

It is interested to notice that 2002 and 2003 trials have showed significantly differences in the thermal effect of the soil solarization even having used the same plastic materials (figures 9, 10, 11 and 12). This can be explained because of summer 2002 was one of the coldest summers of the last 50 years, on the contrary summer 2003 was one of the warmest of the last 50 years. These climatic differences, especially in open field, made 2003 soil solarization much more efficient than the 2002 soil solarization treatment.

\section{Conclusions}

From the mechanical characterization it can be established that the new films, except for the polyesterammide biodegradable plastic film, have demonstrated values of tearing strength resistance and percentage elongation at break superior to the minimum required by the European norm prEN 13655 [15]. Specifically, it has been shown that only the biodegradable, both corn starch and polyesterammide based, films were characterized by a rapid decline in mechanical characteristics; nonetheless, for the corn starch one it is important to note that such a rapid decline was not accompanied by a reduction in thermal performance, especially in greenhouse, that were always similar to the other plastic films. Furthermore, a decline in mechanical properties of the biodegradable film is an expected behavior which is due mostly to the processes of degradation that the film undergoes during its use, in order to avoid its collection and disposal.

The spectroradiometrical characterization has put into evidence that in the UV-VIS-NIR $[190 \div 2,500]$ $\mathrm{nm}$ the co-extruded ultra-thin film and the traditional films have shown average values of elevated transmittance; on the contrary, the corn starch biodegradable film, probably because of its lactescent color, registered a lower transmittance percentage; on the contrary, the corn starch biodegradable film in the IR $[2,500 \div 12,500] \mathrm{nm}$ was characterized by transmittance levels very low in the range especially from 8,000 to $10,000 \mathrm{~nm}$, while the co-extrusive ultra-thin film registered rather high transmittance values, especially compared to those obtained by the EVA.

In conclusion, this study supplied positive indications about the practice of soil solarization, confirming 


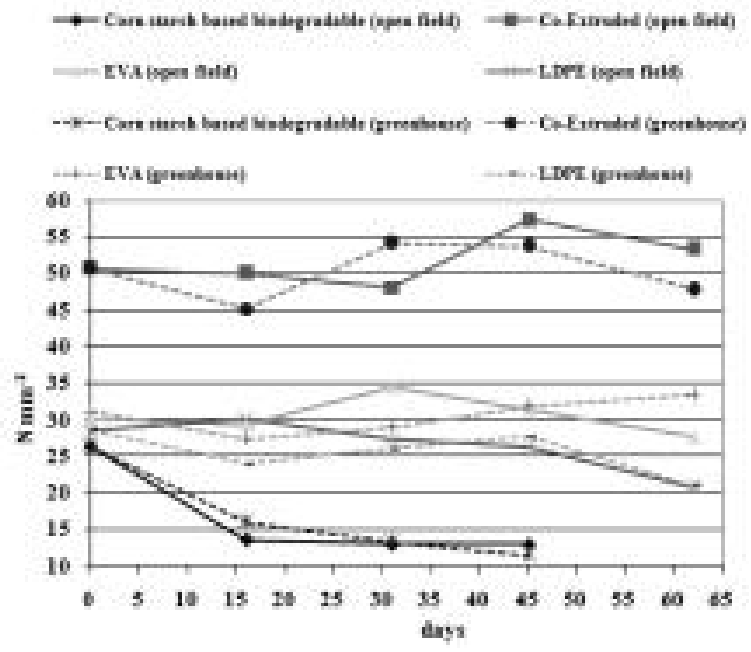

Fig. 5 - Ultimate tensile strength of plastic films in year 2002.

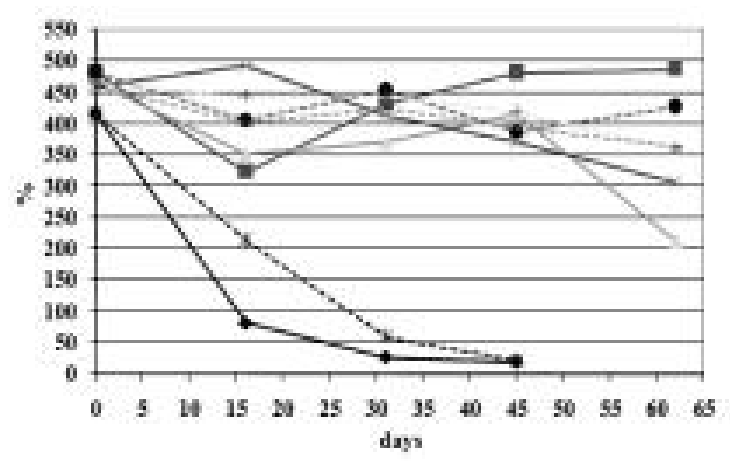

Fig. 6 - Percentage elongation at break of plastic films in year 2002.

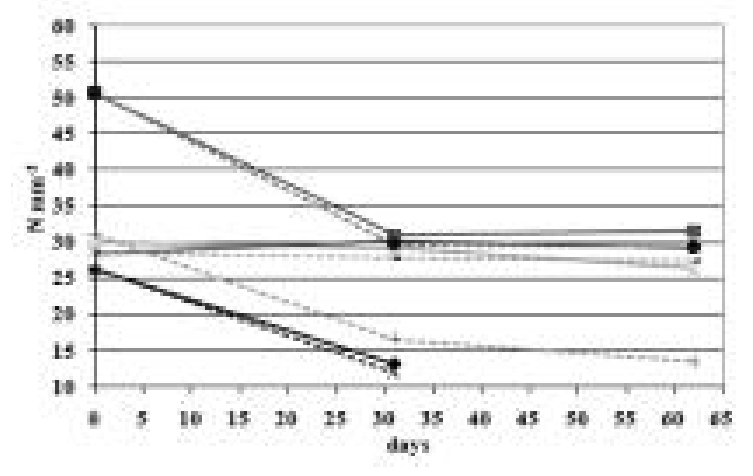

Fig. 7 - Ultimate tensile strength of plastic films in year 2003.

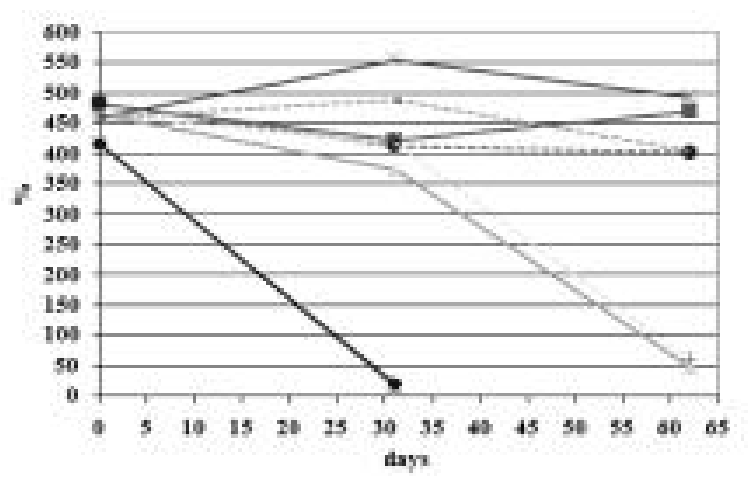

Fig. 8 - Percentage elongation at break of plastic films in year 2003.

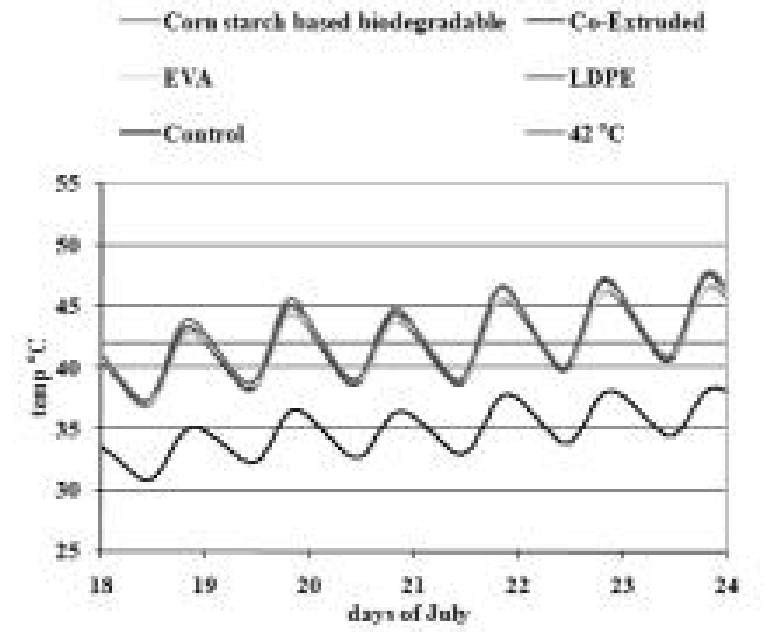

Fig. 9 - Soil temperature at $20 \mathrm{~cm}$ depth in greenhouse in year 2002.

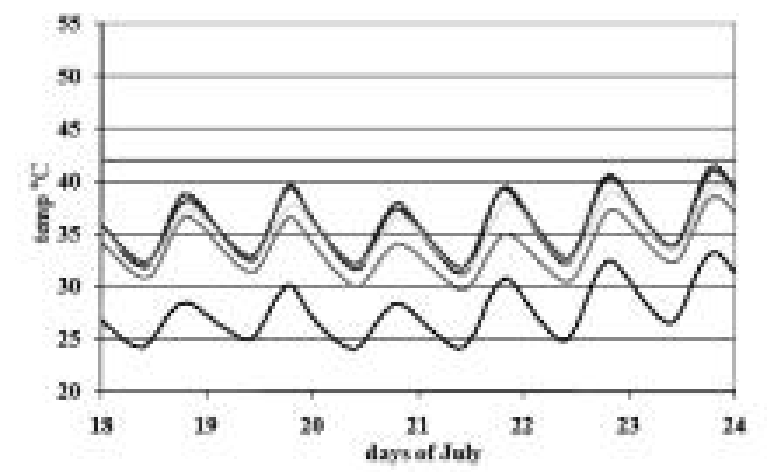

Fig. 10 - Soil temperature at $20 \mathrm{~cm}$ depth in open field in year 2002

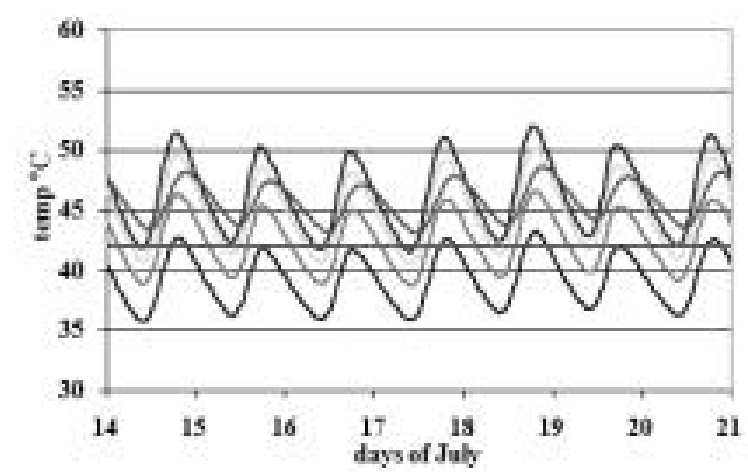

Fig. 11 - Soil temperature at $20 \mathrm{~cm}$ depth in greenhouse in year 2003.

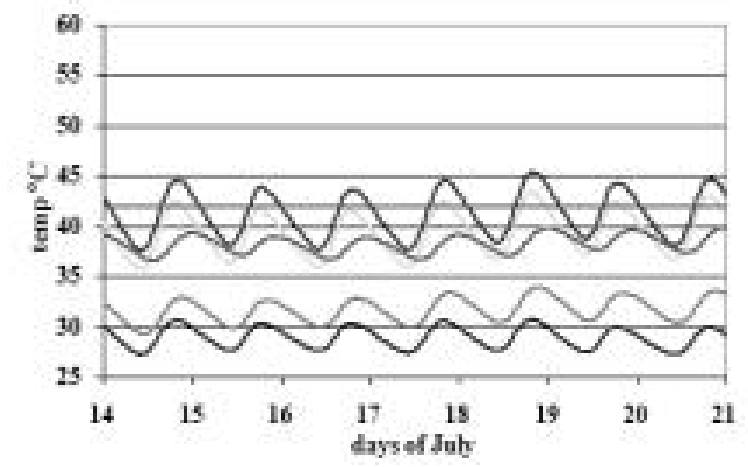

Fig. 12 - Soil temperature at $20 \mathrm{~cm}$ depth in open field in year 2003 . 


\begin{tabular}{|c|c|c|c|c|}
\hline \multirow{2}{*}{$\begin{array}{l}\text { Solarizing } \\
\text { films }\end{array}$} & \multirow{2}{*}{$\begin{array}{c}\text { Depth } \\
(\mathrm{cm})\end{array}$} & \multicolumn{3}{|c|}{$\begin{array}{c}\text { Greenhouse } \\
\text { soil thermal levels }\end{array}$} \\
\hline & & $\begin{array}{c}40-45 \\
{ }^{\circ} \mathrm{C} \\
\end{array}$ & $\begin{array}{c}46-50 \\
{ }^{\circ} \mathrm{C} \\
\end{array}$ & $\begin{array}{c}51-60 \\
{ }^{\circ} \mathrm{C} \\
\end{array}$ \\
\hline \multirow{4}{*}{$\begin{array}{c}\text { Corn starch } \\
\text { based } \\
\text { biodegradable }\end{array}$} & 2 & 224 & 158 & 133 \\
\hline & 10 & 374 & 266 & 103 \\
\hline & 20 & 594 & 192 & 0 \\
\hline & 30 & 817 & 0 & 0 \\
\hline \multirow{4}{*}{ Co-Extruded } & 2 & 233 & 299 & 131 \\
\hline & 10 & 418 & 457 & 203 \\
\hline & 20 & 613 & 341 & 83 \\
\hline & 30 & 567 & 216 & 76 \\
\hline \multirow{4}{*}{ EVA } & 2 & 457 & 338 & 128 \\
\hline & 10 & 416 & 418 & 217 \\
\hline & 20 & 735 & 252 & 0 \\
\hline & 30 & 857 & 163 & 0 \\
\hline \multirow{4}{*}{ LDPE } & 2 & 245 & 150 & 147 \\
\hline & 10 & 410 & 379 & 193 \\
\hline & 20 & 658 & 268 & 2 \\
\hline & 30 & 698 & 157 & 0 \\
\hline \multirow{4}{*}{$\begin{array}{c}\text { Control } \\
\text { (uncovered } \\
\text { soil) }\end{array}$} & 2 & 146 & 118 & 96 \\
\hline & 10 & 289 & 166 & 0 \\
\hline & 20 & 224 & 0 & 0 \\
\hline & 30 & 5 & 0 & 0 \\
\hline
\end{tabular}

\begin{tabular}{|c|c|c|c|c|}
\hline \multirow{2}{*}{$\begin{array}{l}\text { Solarizing } \\
\text { films }\end{array}$} & \multirow{2}{*}{$\begin{array}{c}\text { Depth } \\
\text { (cm) }\end{array}$} & \multicolumn{3}{|c|}{$\begin{array}{c}\text { Open field } \\
\text { soil thermal levels }\end{array}$} \\
\hline & & $\begin{array}{c}40 \text { - } 45 \\
{ }^{\circ} \mathrm{C} \\
\end{array}$ & $\begin{array}{c}46-50 \\
{ }^{\circ} \mathrm{C} \\
\end{array}$ & $\begin{array}{c}51-60 \\
{ }^{\circ} \mathrm{C} \\
\end{array}$ \\
\hline \multirow{4}{*}{$\begin{array}{l}\text { Corn starch } \\
\text { based } \\
\text { biodegradable }\end{array}$} & 2 & 35 & 17 & 0 \\
\hline & 10 & 196 & 0 & 0 \\
\hline & 20 & 90 & 0 & 0 \\
\hline & 30 & 0 & 0 & 0 \\
\hline \multirow{4}{*}{ Co-Extruded } & 2 & 147 & 145 & 182 \\
\hline & 10 & 236 & 201 & 14 \\
\hline & 20 & 531 & 11 & 0 \\
\hline & 30 & 328 & 0 & 0 \\
\hline \multirow{4}{*}{ EVA } & 2 & 108 & 91 & 90 \\
\hline & 10 & 259 & 125 & 0 \\
\hline & 20 & 424 & 0 & 0 \\
\hline & 30 & 298 & 0 & 0 \\
\hline \multirow{4}{*}{ LDPE } & 2 & 170 & 84,5 & 80 \\
\hline & 10 & 203 & 148 & 8 \\
\hline & 20 & 176 & 0 & 0 \\
\hline & 30 & 0 & 0 & 0 \\
\hline \multirow{4}{*}{$\begin{array}{l}\text { Control } \\
\text { (uncovered } \\
\text { soil) }\end{array}$} & 2 & 71 & 64 & 20 \\
\hline & 10 & 0 & 0 & 0 \\
\hline & 20 & 0 & 0 & 0 \\
\hline & 30 & 0 & 0 & 0 \\
\hline
\end{tabular}

TABLE 6 - Number of hours for temperature range at different soil depth in greenhouse and in open field (2003).

the efficiency of the eco-compatible solarizing plastic films, that is, corn starch biodegradable films and coextruded ultra-thin. The research has demonstrated that these innovative plastic films work well in greenhouse but do not appear to be suitable for soil solarization in open field. Therefore, in protected cultivations they are compatible to agricultural practices safeguarding to the environment through the reduction of plastic refuse and of the substitution of the methyl bromide use, which phase-out was applied in 2005.

\section{Acknowledgements}

The author acknowledgements Dr. Donato Castronuovo, Di.T.Ec. dept., for his help during field and lab trials.

\section{References}

[1] Candido V., Miccolis V., Castronuovo D., Basile M., D' AdDABBo T., Effect of repeated applications of soil solarization in greenhouse in Southern Italy, Acta Horticulturae, (2005) 698, 187-193.

[2] Cascone G., Arcidiacono C., D'Emilio A., MazZARELLA R., Efficacia di film plastici innovativi per la solarizzazione del terreno sotto serra. Convegno Nazionale "L'utilizzo dei materiali plastici innovative in agricoltura, (2004), Potenza (I), 61:77.

[3] Castronuovo D., Caratterizzazione meccanica, radiometrica ed agronomica di materiali plastici innovativi per la pacciamatura delle colture ortive e per la solarizzazione del terreno. Tesi di dottorato in $\mathrm{Ge}$ nio rurale XVI, (2004) Università degli Studi della Basilicata, Potenza (I).

[4] Castronuovo D., Candido V., Margiotta S., Manera C., Miccolis V., Basile M., D'Addabbo T., Potential of a corn starch-based biodegradable pla- 
stic film for soil solarization. Acta Horticulturae, (2005) 698, 201-206.

[5] JouËT J.P., Plastics in the world. Plasticulture, (2001) 120, 108-126.

[6] Katan J., Soil disinfestations: one minute fore methyl bromide phase out., Acta Horticulturae, (2005) 698, 19-26.

[7] Katan J., Solar heating of soil for control of soilborne pests, Annual Review of Phytopathology, (1981) 19, 211-236.

[8] Katan J., Greenberger A., Alon H., Grinstein A., Solar heating by polyethylene mulching for the control of diseases caused by soil-borne pathogens. Phytopathology, (1976) 66, 683-688.

[9] Manera C., Materiali plastici innovativi per la protezione delle colture e la solarizzazione del terreno, Convegno Nazionale "L'utilizzo dei materiali plastici innovative in agricoltura, (2004), Potenza (I), 3-28.

[10] Manera C., Margiotta S., Castronuovo D., Soil solarization tests in greenhouses using innovative and biodegradable plastic films, Proceeding of the International Conference XXX CIOSTA, (2003), volume 2, 786-799.

[11] Manera C., Margiotta S., Gatta G., La solarizzazione in pieno campo ed in serra: esperienze a confronto. Atti del Convegno Nazionale di Ingegneria Agraria "Ingegneria agraria per lo sviluppo dei paesi del mediterraneo", (2001), Vieste (I).

[12] Margiotta S., Castronuovo D., Candido V., MicColis V., Manera C., Prove di solarizzazione con film plastici innovativi: aspetti tecnici ed agronomici. Atti del Convegno Nazionale di Ingegneria Agraria "L'ingegneria agraria per lo sviluppo sostenibile dell'area mediterranea", (2005), Catania (I).

[13] Pacini L., Colture Protette, (2004) 11, 44-46.

[14] Picuno P., Sica C., Mechanical and spectroradiometrical characteristics of agricultural Recycled plastic flms, CIGR Journal of Scientific Research and Development., (2004).

[15] PREN 13655, Plastics-Mulching thermoplastics films for use in agriculture and horticulture. European Committee for Standardization, (2001).

[16] Russo G., Candura A., Scarascia Mugnozza G., Soil solarization with biodegradable plastic film: two years of experimental tests, International Conference on Sustainable Greenhouse Systems, (2005) Leuven (B), 717-724.

[17] Russo G., Scarascia Mugnozza G., Film sperimen- tali e biodegradabili per la solarizzazione del terreno agrario. Convegno Nazionale "L'utilizzo dei materiali plastici innovative in agricoltura", (2004), Potenza (I), 87:101.

\section{SUMMARY}

Soil solarization relies on solar radiation being converted to heat for the killing of soilborne pathogens. On one hand, this technique can be considered as an environmentally-friendly way to manage soilborne pests, as an alternative of methyl bromide phased-out in 2005, than using chemicals. On the other hand, high employment of traditional plastic sheets in agriculture causes the production of enormous quantities of waste, whose inappropriate management might have negative effects on the environment.

In order to determine a reduction of the charge of plastic waste and to facilitate the waste disposal, one of the most interesting approaches, from an environmental point of view, lies in the location of innovatory plastic films such as co-extruded ultrathin films, which are able to reduce the plastic quantity to be managed, and biodegradable laminates, which after a first usage, will spontaneously start up a degradation process that avoids their collection and their consequent disposal.

Beside the ecological proprieties of these innovative films, it is necessary to study their technical and agronomical behavior in order to determine their efficiency and the possibility to be used in place of the traditional plastic films.

This paper represents a review of the researches carrier out by the Technical Economics Department of the University of Basilicata (Italy) in the last years (1999, 2000, 2002 and 2003) on the technical performances of some innovative plastic films used for soil solarization.

Key words: biodegradable plastic film, ultra thin co-extruded plastic film, mechanical characterization, spectroradiometrical characterization, soil solarization. 